\title{
Studies on Carbamates
}

\author{
V. The Carbamates of $\alpha$-Alanine and $\beta$-Alanine
}

ARNE JENSEN and CARL FAURHOLT

The Royal Danish School of Pharmacy, Copenhagen, Denmark

1. In previous investigations has been studied the equilibrium conditions and reaction mechanism of the formation and decomposition in aqueous medium of ammonium carbamate ${ }^{1,2}$, and of the carbamates formed by dimethylamine ${ }^{2}$, ethylamine and diethylamine ${ }^{3}$, and hydrazine ${ }^{4}$.

The present investigation deals with the corresponding conditions with regard to the carbamates formed by $\alpha$-alanine and $\beta$-alanine. The conditions have been shown to be analogous to those of the carbamates previously investigated, only differing somewhat quantitatively.

On the following pages $\alpha$-alanine, $\mathrm{CH}_{3} \cdot \mathrm{CHNH}_{3}{ }^{+} \cdot \mathrm{COO}^{-}$, as well as $\beta$-alanine, $\mathrm{CH}_{2} \mathrm{NH}_{3}{ }^{+} \cdot \mathrm{CH}_{2} \cdot \mathrm{COO}^{-}$, both of which should be regarded as amminium ions, will frequently be referred to as " $\mathrm{AmH}^{+}$". Accordingly the corresponding bases $\mathrm{CH}_{3} \cdot \mathrm{CHNH}_{2} \cdot \mathrm{COO}^{-}$and $\mathrm{CH}_{2} \mathrm{NH}_{2} \cdot \mathrm{CH}_{2} \cdot \mathrm{COO}^{-}$will be referred to as "Am". "carbamates" signify the carbamates of the alanines, i. e. $\mathrm{CH}_{3} \cdot \mathrm{CHNHCOO}^{-} \cdot \mathrm{COO}^{-}$and $\mathrm{CH}_{2} \mathrm{NHCOO}^{-} \cdot \mathrm{CH}_{2} \cdot \mathrm{COO}^{-}$.

2. The following substances have been used in the present experiments:

$d l$ - $\alpha$-Alanine, L. Light \& Co. Ltd., consisting of small needle-shaped crystals, the melting point of which was found to be 260 to $262^{\circ} \mathrm{C}$, and the molecular weight, determined by means of the Kjeldahl method, was 89.25 (theoretically 89.09). $\beta$-Alanine was specially prepared and furnished us through the generosity of Løvens kemiske Fabrik (Leo Pharmaceutical Products), Copenhagen. The analysis was stated to yield the following results: melting point $198^{\circ} \mathrm{C}, 99.5 \%$ of alanine by formol titration, $98.3 \%$ of alanine by the Kjeldahl method, less than $0.1 \%$ loss by drying, less than $0.1 \%$ of ash, and a slight trace of halogen. We found the melting point to be $196-199^{\circ} \mathrm{C}$, and $98.4 \%$ of alanine by the Kjeldahl method. 
3. No attempt has been made to isolate the carbamates and carbonates as substances. Solutions of carbamate were prepared by neutralizing the amminium ion with the equivalent amount of sodium hydroxide, e.g. in the case of $\alpha$-alanine " $\mathrm{CH}_{3} \cdot \mathrm{CHNH}_{3}^{+} \cdot \mathrm{COO}^{-}+\mathrm{Na}^{+}+\mathrm{OH}^{-}=\mathrm{CH}_{3} \cdot \mathrm{CHNH}_{2} \cdot \mathrm{COO}^{-}$ $+\mathrm{Na}^{+}+\mathrm{H}_{2} \mathrm{O}$ ", whereupon a deficient amount of carbon dioxide was added to the solution; practically all of the carbon dioxide is thus converted to carbamate " $\mathrm{CH}_{3} \cdot \mathrm{CHNH}_{2} \cdot \mathrm{COO}^{-}+\mathrm{CO}_{2}=\mathrm{CH}_{3} \cdot \mathrm{CHNHCOO}^{-} \cdot \mathrm{COO}^{-}+\mathrm{H}^{+}$", the latter of course being neutralized by excess amine. Solutions of carbonate were made from equivalent amounts of amminium ion and sodium carbonate, " $2 \mathrm{CH}_{3} \cdot \mathrm{CHNH}_{3}{ }^{+} \cdot \mathrm{COO}^{-}+2 \mathrm{Na}^{+}+\mathrm{CO}_{3}^{--}=\left(\mathrm{CH}_{3} \cdot \mathrm{CHNH}_{3} \cdot \mathrm{COO}_{2}^{-}\right)_{2} \mathrm{CO}_{3}+$ $2 \mathrm{Na}^{+}$. Solutions of carbamate as well as solutions of carbonate thus contain sodium ions; this, however, is of no importance in the present investigation.

4. The method of analysis was, as in previous investigations, precipitation with barium chloride, i.e. barium chloride is added to $100 \mathrm{ml}$ of the solution, if necessary previously made alkaline by the addition of sodium hydroxide. In this way the carbonate is precipitated, whilst the carbamate remains dissolved. By centrifugation the precipitate and the supernate are separated as quickly as possible. If the supernate is left standing or is heated, the carbamate decomposes forming a precipitate of barium carbonate, the amount of which can be determined by titration with $0.1 \mathrm{~N}$ hydrochloric acid.

Since solutions containing only carbonate, and no carbamate, upon precipitation with barium chloride yield a supernate precipitating a small amount of barium carbonate, it was found necessary to carry out blank experiments. The value of the blanks amounts to about 3 units of the percentage. All of the experimental results in the later tables are corrected with regard to the value of the blank experiments.

5. All of the experiments were carried out at $18^{\circ} \mathrm{C}$, and the velocity constants were calculated by means of Brigg's logarithms, the time unit being the minute.

As in earlier investigations the activity coefficient $f$ of monovalent ions was calculated from the expression of Bjerrum ${ }^{5}:-\log f=0.3 \sqrt[3]{\sqrt{\text { ion }}}$.

6. The calculation of certain experiments was carried out on the basis of the acidic dissociation constant, $K_{\mathrm{AmH}}^{\prime}$, for

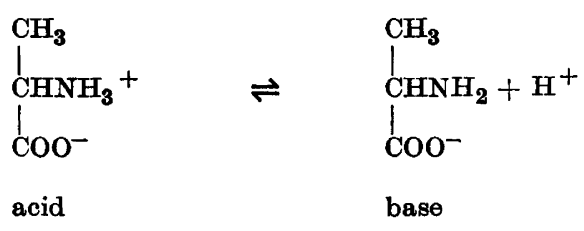


and the corresponding value of $\beta$-alanine. These constants were calculated by us (Table 1) on the basis of determinations of the hydrogen ion activity in solutions containing equal moles of corresponding acid and base, prepared by the mixing of alanine with half the number of moles of sodium hydroxide. The determinations were carried out by means of a hydrogen electrode against a $0.1 N$ calomel electrode, and were calculated from the expression $\mathrm{p} a_{\mathrm{H}}=$ $-\log a_{\mathrm{H}}+=\left(E-E_{0}\right) \frac{F \log e}{R T}, E_{0}$ being fixed at $0.3360^{6}$. No corrections were made for the diffusion potentials, these being insignificant as in the glycine measurements in the investigation just cited.

Table 1. Determination of the acidic dissociation constants of the alanines.

\begin{tabular}{|c|c|c|c|}
\hline \multirow[b]{2}{*}{$c_{\text {acid }}$} & \multirow[b]{2}{*}{$c_{\text {base }}$} & \multicolumn{2}{|c|}{$\mathrm{p} a_{\mathrm{H}}$} \\
\hline & & $\alpha$ & $\beta$ \\
\hline 0.1 & 0.1 & 10.00 & 10.42 \\
\hline 0.05 & 0.05 & 10.01 & 10.42 \\
\hline 0.02 & 0.02 & 10.02 & 10.41 \\
\hline 0.01 & 0.01 & 9.99 & 10.40 \\
\hline & $K^{\prime}:$ & 10.00 & 10.41 \\
\hline
\end{tabular}

accordingly the expression

$$
\frac{a_{\mathrm{H}^{+}}+c_{\mathrm{CH}_{3} \cdot \mathrm{CHNH}_{2} \cdot \mathrm{COO}^{-}}}{c_{\mathrm{CH}_{8} \cdot \mathrm{CHNH}_{8}{ }^{+} \cdot \mathrm{COO}^{-}}}=K_{\mathrm{AmH}^{+}}^{\prime}
$$

and the corresponding one for $\beta$-alanine has a practically constant value independant of the ion concentration. From this it may be further concluded that the activity coefficients of the divalent ampho-ion $\mathrm{CH}_{3} \cdot \mathrm{CHNH}_{3}^{+} \cdot \mathrm{COO}^{-}$ $\left(\mathrm{CH}_{2} \mathrm{NH}_{3}^{+} \cdot \mathrm{CH}_{2} \cdot \mathrm{COO}^{-}\right.$, respectively) are of practically the same magnitude as are those of the monovalent ion $\mathrm{CH}_{3} \cdot \mathrm{CHNH}_{2} \cdot \mathrm{COO}^{-}\left(\mathrm{CH}_{2} \mathrm{NH}_{2} \cdot \mathrm{CH}_{2} \cdot \mathrm{COO}^{-}\right.$, respectively). This fact is used later on.

Onthereaction "amine+carbon dioxide $\rightleftharpoons$ carbamic a c i d"

1. The reaction from left to right. $500 \mathrm{ml}$ of an aqueous solution of alanine, containing excess sodium hydroxide, were placed in a 2 liter flask; if, for instance, $250 \mathrm{ml}$ of $0.2 M$ alanine are added to $250 \mathrm{ml}$ of $0.4 M \mathrm{NaOH}$, the 
resulting solution will have $c_{\mathrm{NaOH}}=0.10$ and $c_{\mathrm{Am}}=0.10$. In the gas phase above this solution approximately $250 \mathrm{ml}$ of carbon dioxide were substituted for an equal amount of atmospheric air, and the flask was shaken vigorously for about 2 minutes to obtain absorption of the carbon dioxide. In $100 \mathrm{ml}$ of the reaction mixture the carbamate content was determined immediately, and in another $100 \mathrm{ml}$ of the reaction mixture carbamate + carbonate were determined. Per cent carbamate in table 2 indicates how many per cent of the carbon dioxide absorbed have been converted to carbamate.

Table 2. Carbon dioxide in alanine $+\mathrm{NaOH} .18^{\circ}$.

\begin{tabular}{|c|c|c|c|c|c|c|c|c|c|c|}
\hline & \multicolumn{2}{|c|}{ Initial solution } & \multirow{2}{*}{$\mid \begin{array}{c}\text { Absorbed } \\
\mathrm{CO}_{2} \\
\mathrm{Mol} \text { /liter }\end{array}$} & \multirow{2}{*}{$\begin{array}{c}\% \\
\text { carba- } \\
\text { mate }\end{array}$} & \multicolumn{2}{|c|}{ Final solution } & \multicolumn{2}{|c|}{ Mean } & \multicolumn{2}{|c|}{$k_{\mathrm{CO}_{2} \cdot \mathrm{Am}}$} \\
\hline & $c_{\mathrm{NaOH}}$ & $c_{\mathrm{Am}}$ & & & $c_{\mathrm{NaOH}}$ & $c_{\text {Am }}$ & $c_{\mathrm{NaOH}}$ & $c_{\mathrm{Am}}$ & & Mean \\
\hline \multirow{3}{*}{$\alpha$} & 0.10 & 0.10 & 0.0193 & 41 & 0.07 & 0.09 & 0.09 & 0.10 & $10^{4.81}$ & \multirow{3}{*}{$10^{4.82}$} \\
\hline & 0.10 & 0.15 & 0.0188 & 55 & 0.07 & 0.14 & 0.09 & 0.15 & $10^{4.87}$ & \\
\hline & 0.06 & 0.09 & 0.0116 & 49 & 0.04 & 0.08 & 0.05 & 0.09 & $10^{4.77}$ & \\
\hline \multirow{3}{*}{$\beta$} & 0.10 & 0.10 & 0.0175 & 54 & 0.07 & 0.09 & 0.09 & 0.10 & $10^{5.05}$ & \multirow{3}{*}{$10^{5.04}$} \\
\hline & 0.20 & 0.10 & 0.0154 & 34 & 0.17 & 0.10 & 0.19 & 0.10 & $10^{5.02}$ & \\
\hline & 0.20 & 0.20 & 0.0129 & 53 & 0.18 & 0.19 & 0.19 & 0.20 & $10^{5.05}$ & \\
\hline
\end{tabular}

The results of the experiments can be interpreted in that carbon dioxide is reacting partly with the amine, partly with the hydroxyl ion:

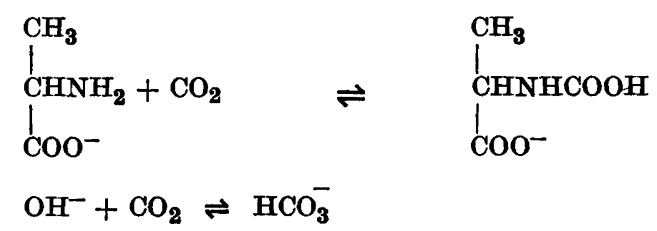

according to the following equation:

$$
\frac{\mathrm{d} c_{\mathrm{CO}_{2}}}{\mathrm{~d} t}=-\left(k_{\mathrm{CO}_{2} \cdot \mathrm{Am}} \cdot c_{\mathrm{Am}}+k_{\mathrm{CO}_{2} \cdot \mathrm{OH}^{-}} \cdot c_{\mathrm{OH}^{-}}\right) c_{\mathrm{CO}_{2}}
$$

For the interrelation between the percentages of carbamate formed and carbonate formed we have the expression

$$
\frac{k_{\mathrm{CO}_{2} \cdot \mathrm{Am}} \cdot c_{\mathrm{Am}}}{k_{\mathrm{CO}_{2} \cdot \mathrm{OH}^{-}} \cdot c_{\mathrm{OH}^{-}}}=\frac{\text { per cent carbamate }}{\text { per cent carbonate }}
$$


Upon introduction into this expression of the mean values of the concentrations at the beginning and at the end of the experiment for $c_{\mathrm{OH}}$ and $c_{\mathrm{Am}}$, and of the value $10^{5,02}$ for $k_{\mathrm{CO}_{2} \cdot \mathrm{OH}^{-}}{ }^{7}$, the values $10^{4,82}$ and $10^{5,04}$ are obtained for $k_{\mathrm{CO}_{2} \text {. Am }}$ for $\alpha$-alanine and $\beta$-alanine, respectively, i.e. carbon dioxide reacts with $\alpha$-alanine approximately 1.5 times slower than it does with $\beta$-alanine.

2. The reaction from right to left. Previously it has been shown that ordinary carbamate, $\mathrm{NH}_{2} \mathrm{COO}^{-}$, by acidification is extremely quickly and completely decomposed into carbon dioxide and ammonia, or rather ammonium ion. The decomposition of the alanine carbamates in acid solution has not been investigated directly. As shown in a previous investigation it is possible, however, by means of the velocity constant, $k_{\mathrm{CO}_{2} \cdot \mathrm{Am}}$, to estimate that these carbamates, too, are decomposed practically instantaneously and completely in acid solution.

3. The equilibrium "carbamate $\rightleftharpoons$ carbonate". In acid and in strongly basic solutions the carbamates are practically completely decomposed into carbon dioxide and carbonate, respectively, but in a weakly basic solution an equilibrium, which can be easily determined, is established,

$$
\text { carbamate } \rightleftharpoons \text { carbonate }
$$

For the determination of the equilibrium value $0.02 M$ solutions of $(\mathrm{AmH})_{2} \mathrm{CO}_{3}$ containing $\mathrm{Am}$ and $\mathrm{AmH}^{+}$as well, were prepared, see Table 3. Accordingly the initial composition of the solution in e.g. the experiment “0.02 $M(\mathrm{AmH})_{2} \mathrm{CO}_{3}, 0.05 M \mathrm{AmH}^{+}, 0.05 M$ Am" was $0.14 M$ alanine, 0.05 $M \mathrm{NaOH}$ and $0.02 M \mathrm{Na}_{2} \mathrm{CO}_{3}$. The solutions were left until an equilibrium was established. In the table " $\%$ carbamate" indicates the percentage of carbonate converted to carbamate. The constitution of the equilibrium solutions was calculated. $\mathrm{p} K$ of the carbamic acids supposedly being approximately 5 the amount of free carbamic acid present in these solutions is insignificant, i. e. $c_{\text {carbamate ion }}$ can be fixed at that of the carbamate found analytically. The concentrations of $\mathrm{AmH}^{+}, \mathrm{Am}$ and $\mathrm{HCO}_{3}^{-}$were calculated from the following expressions:

$$
\frac{c_{\mathrm{Am}} \cdot c_{\mathrm{HCO}_{3}^{-}}}{c_{\mathrm{AmH}^{+}} \cdot c_{\mathrm{CO}_{3}--} \cdot f}=\frac{K_{\mathrm{AmH}^{\prime}}^{\prime}}{K_{\mathrm{HCO}_{3}-}}=\frac{K_{\mathrm{AmH}^{\prime}}}{10^{-10.3}}
$$

$$
\begin{aligned}
& c_{\text {carbamate }}+c_{\mathrm{HCO}_{3}-}+c_{\mathrm{CO}_{3}--}=\text { total concentration of } \mathrm{CO}_{2} \\
& c_{\text {carbamate }}+c_{\mathrm{AmH}^{+}}+c_{\mathrm{Am}}=\text { total concentration of alanine, } \\
& c_{\mathrm{Am}}=c_{\mathrm{Am}}(\text { column } 4 \text { in the table })+c_{\mathrm{HCO}_{3}-}, \\
& \text { where } c_{\mathrm{AmH}}+=c_{\mathrm{CH}_{3} \cdot \mathrm{CHNH}_{3}}+{ }_{\mathrm{COO}}-\left(c_{\mathrm{CH}_{3} \mathrm{NH}_{2}}+\cdot \mathrm{CH}_{2} \cdot \mathrm{COO}^{-} \text {, respectively), and } c_{\mathrm{Am}}=\right.
\end{aligned}
$$
$c_{\mathrm{CH}_{3}} \cdot \mathrm{CHNH}_{2} \cdot \mathrm{COO}^{-}\left(c_{\mathrm{CH}_{3} \mathrm{NH}_{2}} \cdot \mathrm{CH}_{2} \cdot \mathrm{COO}^{-}\right.$, respectively $)$. 
Table 3. The solutions of carbonate-carbamate in equilibrium. $18^{\circ}$.

\begin{tabular}{|c|c|c|c|c|c|c|c|c|c|c|}
\hline & \multicolumn{3}{|c|}{ Initial solution } & \multirow{2}{*}{$\begin{array}{c}\% \\
\text { carba- } \\
\text { mate }\end{array}$} & \multicolumn{4}{|c|}{ Equilibrium } & \multicolumn{2}{|c|}{$K_{E q}$} \\
\hline & $c_{(\mathrm{AmH})_{2}} \mathrm{CO}_{3}$ & $c_{\mathrm{AmH}}+$ & $c_{\mathrm{Am}}$ & & $c_{\mathrm{AmH}}+$ & $c_{\mathrm{Am}}$ & $\underset{\text { mate }}{c_{\text {carba- }}}$ & $c_{\mathrm{HCO}_{2}-}$ & & Mean \\
\hline$\alpha$ & $\begin{array}{l}0.02 \\
0.02\end{array}$ & $\begin{array}{l}0.05 \\
0.10\end{array}$ & $\begin{array}{l}0.05 \\
0.10\end{array}$ & $\begin{array}{l}26^{1} \\
39^{2}\end{array}$ & $\begin{array}{l}0.075 \\
0.125\end{array}$ & $\begin{array}{l}0.060 \\
0.108\end{array}$ & $\begin{array}{l}0.0052 \\
0.0078\end{array}$ & $\begin{array}{l}0.0097 \\
0.0075\end{array}$ & $\begin{array}{l}10^{-0.96} \\
10^{-0.99}\end{array}$ & $10^{-0.97}$ \\
\hline$\beta$ & $\begin{array}{l}0.02 \\
0.02\end{array}$ & $\begin{array}{l}0.05 \\
0.10\end{array}$ & $\begin{array}{l}0.05 \\
0.10\end{array}$ & $\begin{array}{l}44^{3} \\
59^{4}\end{array}$ & $\begin{array}{l}0.076 \\
0.125\end{array}$ & $\begin{array}{l}0.055 \\
0.104\end{array}$ & $\begin{array}{l}0.0089 \\
0.0117\end{array}$ & $\begin{array}{l}0.0049 \\
0.0035\end{array}$ & $\begin{array}{l}10^{-1.52} \\
10^{-1.51}\end{array}$ & $10^{-1.51}$ \\
\hline
\end{tabular}

1 Mean of 4 determinations: $25.3,27.4,25.4,25.7$.

$2 "$ " $4 \quad 39.1,39.1,39.1,38.5$.

3 " $444.8,45.0,44.1,44.0$.

4 " $3 \quad 57.5,60.3,58.1$.

Further the equilibrium constants of the reactions "carbamate ion $+\mathrm{H}_{2} \mathrm{O}$ $=\mathrm{HCO}_{3}^{-}+\mathrm{Am}^{\prime}$, i. e.

$$
\frac{a_{\mathrm{Am}} \cdot a_{\mathrm{HCO}_{3}^{-}}}{a_{\text {carbamate ion }}}=\frac{c_{\mathrm{CH}_{3} \cdot \mathrm{CHNH}_{2} \cdot \mathrm{COO}^{-}} \cdot f \cdot c_{\mathrm{HCO}_{3}^{-}} \cdot f}{c_{\mathrm{CH}_{3} \cdot \mathrm{CHNHCOO}^{-} \cdot \mathrm{COO}^{-}} \cdot f^{2}}=K_{\mathrm{E} q}
$$

and the analogous one for $\beta$-alanine, in both of which the activity coefficients neutralize each other, were calculated. The constants are listed in the last column of Table 3.

The velocity of the conversion "carbamate $\rightleftharpoons$ c a r b o n a t e"

In Table 4 are listed data on the velocity when equilibrium is ensuing in buffer solutions of $\mathrm{p} a_{\mathrm{H}}=$ about 10. All experiments are from the carbonate side.

In addition to the experimental data are listed in Table 4 in the column $k_{\text {amate }}+k_{\text {onate }}$ the values of $\frac{1}{t} \log \frac{K \cdot a}{K \cdot a-(1+K) x}$, the expression for a process which is monomolecular from both sides and which does not run to completion. The constant $K$ signifies the relation between the equilibrium values of the concentrations of carbamate and carbonate. The sum " $k_{\text {amate }}+$ $k_{\text {onate }}$ " is approximately constant within each experiment. $k_{\text {amate }}$ is the 
Table 4. Velocity constants for the process: carbamate $\rightleftharpoons$ carbonate; $p a_{\mathrm{H}}=c a .10 .18^{\circ}$.

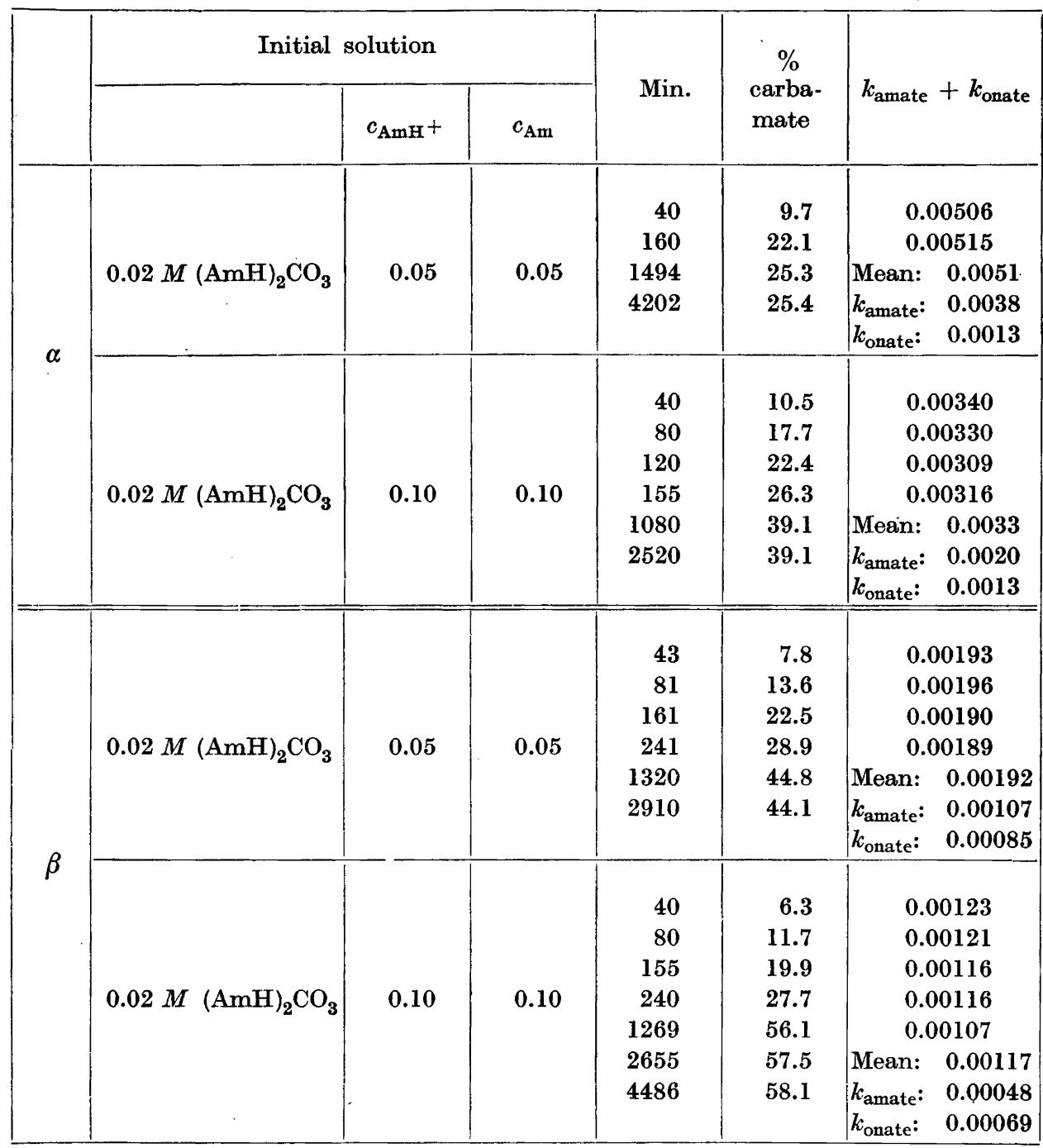

velocity constant for the conversion of carbamate to carbonate, and $k_{\text {onate }}$ the one for the reversed reaction.

By means of $\frac{k_{\text {onate }}}{k_{\text {amate }}}=\frac{\text { equilibrium value of } c_{\text {carbamate }}}{\text { equilibrium value of } c_{\text {carbonate }}}=K$, the values of $k_{\text {amate }}$ and $k_{\text {onate }}$ are obtained. 
In Table 5 are presented data on the decomposition of the carbamates in strong basic solution, $\mathrm{p} a_{\mathrm{r}}=$ about 13. The solutions of the carbamates were prepared by dissolving carbon dioxide in a mixture of practically equal moles alanine and sodium hydroxide and subsequently add the desired excess sodium hydroxide. The initial composition of $e . g$. the solution " $0.018 M$ carbamate, $0.18 M \mathrm{OH}^{-}$and $0.08 M \mathrm{Am}$ " was accordingly $0.10 \mathrm{M}$ alanine, $0.30 M \mathrm{NaOH}$, and $0.018 M \mathrm{CO}_{2} . k_{\text {amate }}$ is the value of $k=\frac{1}{t} \log \frac{a}{a-x}$.

The experiments may be interpreted in a way similar to the one used by the carbamates previously examined. The conversion is a two-stage reaction

$$
\begin{aligned}
\text { Carbonate } & \rightleftharpoons \text { carbon dioxide } \\
\text { carbon dioxide }+ \text { amine } & \rightleftharpoons \text { carbamate }
\end{aligned}
$$

and it is possible to calculate in advance the velocity constants.

The conversion "carbon dioxide $\rightleftharpoons$ carbonate" is known to take place through two reactions: " $\mathrm{CO}_{2}+\mathrm{H}_{2} \mathrm{O} \rightleftharpoons \mathrm{H}_{2} \mathrm{CO}_{3}$ " and " $\mathrm{CO}_{2}+\mathrm{OH}^{-} \rightleftharpoons \mathrm{HCO}_{3}^{- \text {"; }}$ as the $\mathrm{p} a_{\mathrm{H}}$ of the solution is about 10 or more, only the latter reaction need, as previously shown, to be taken into consideration.

$k_{\text {amate }}$ is calculated from the expression previously deduced ${ }^{3}$

$$
k_{\text {amate }}=\frac{k_{\mathrm{CO}_{2} \cdot \mathrm{Am}} \cdot K_{\mathrm{Eq}} \cdot K_{\mathrm{H}_{2} \mathrm{O}} \cdot 1 / K_{\mathrm{CO}_{2}}}{c_{\mathrm{OH}^{-}}+\frac{k_{\mathrm{CO}_{2} \cdot \mathrm{Am}}}{k_{\mathrm{CO}_{2} \cdot \mathrm{OH}^{-}}} \cdot c_{\mathrm{Am}}}
$$

i.e. in order to calculate the velocity at which a carbamate, following the above mentioned sequence of reactions, is decomposed, only two experiments need to be carried out, viz. 1) a determination of the distribution of carbon dioxide on carbamate and carbonate upon introducing the gas into a solution of amine and sodium hydroxide, thus attaining the value of $k_{\mathrm{CO}_{1} \cdot \mathrm{Am}}$, and 2) a determination of the carbamate-carbonate equilibrium value $i . e . K_{E q}$.

From the expression for $k_{\text {amate }}$ it is seen that for a weakly basic solution the $c_{\mathrm{OH}^{-}}$of the denominator is but slight compared to the other term of the denominator, i.e. in such solutions the velocity of the decomposition of carbamate is inversely proportional to the concentration of amine.

$k_{\text {onate }}$ is calculated from the expression previously deduced ${ }^{2}$

$$
k_{\text {onate }}=\frac{k_{\mathrm{HCO}_{3}^{-}}}{1+\frac{a_{\mathrm{H}^{+}}}{K_{\mathrm{H}_{2} \mathrm{CO}_{3}}} \cdot f+\frac{K_{\mathrm{HCO}_{3}-}}{a_{\mathrm{H}^{+}}} \cdot \frac{1}{f}}
$$

The middle term of the denominator being so slight that it is discarded. 
Table 5. Velocity constants for the process: carbamate $\rightarrow$ carbonate; $p a_{\mathrm{H}}=c a .13 .18^{\circ}$.

\begin{tabular}{|c|c|c|c|c|c|c|}
\hline & \multicolumn{3}{|c|}{ Initial solution } & \multirow{2}{*}{ Min. } & \multirow{2}{*}{$\begin{array}{c}\% \\
\text { carba- } \\
\text { mate left }\end{array}$} & \multirow{2}{*}{$k_{\text {amate }}$} \\
\hline & $c_{\text {carbamate }}$ & $c_{\mathrm{NaOH}}$ & $c_{\mathrm{Am}}$ & & & \\
\hline$\alpha$ & 0.018 & 0.18 & 0.08 & \begin{tabular}{|c|}
0 \\
384 \\
1049 \\
1568 \\
2538 \\
2988 \\
3921 \\
ca. 1 month
\end{tabular} & \begin{tabular}{|r|}
100 \\
70.3 \\
36.0 \\
21.7 \\
8.2 \\
5.0 \\
1.8 \\
0
\end{tabular} & $\begin{array}{c}0.000398 \\
0.000423 \\
0.000424 \\
0.000428 \\
0.000437 \\
0.000443 \\
\text { Mean: } 0.00043\end{array}$ \\
\hline \multirow{2}{*}{$\beta$} & 0.019 & 0.18 & 0.08 & \begin{tabular}{c|}
0 \\
362 \\
1382 \\
1744 \\
2906 \\
3381 \\
4210 \\
ca. 2 months
\end{tabular} & \begin{tabular}{|c|}
100 \\
89.2 \\
60.8 \\
53.3 \\
37.2 \\
30.2 \\
22.3 \\
0
\end{tabular} & $\begin{array}{c}0.000137 \\
0.000156 \\
0.000157 \\
0.000148 \\
0.000154 \\
0.000155 \\
\text { Mean: } 0.00015\end{array}$ \\
\hline & 0.020 & 0.18 & 0.18 & \begin{tabular}{c|}
0 \\
402 \\
1350 \\
1855 \\
2715 \\
3182 \\
ca. 1 month
\end{tabular} & \begin{tabular}{c|}
100 \\
90.8 \\
70.4 \\
62.7 \\
50.4 \\
44.6 \\
0
\end{tabular} & $\begin{array}{c}0.000104 \\
0.000113 \\
0.000109 \\
0.000110 \\
0.000110 \\
\text { Mean: } 0.00011\end{array}$ \\
\hline
\end{tabular}

In calculating the values of $k_{\text {amate }}$ and $k_{\text {onate }}$ were used $K_{\mathrm{H}_{\mathrm{z}} \mathrm{O}}=10^{-14.22}$, $K_{\mathrm{CO}_{3}}=10^{-6.52}, K_{\mathrm{HCO}_{3}-}=10^{-10.3}, k_{\mathrm{HCO}_{3}^{-}}=10^{-2.74}, k_{\mathrm{CO}_{2} \cdot \mathrm{OH}^{-}}=10^{-5.02}$ and for $K_{E q}$ the values obtained in the preceding paragraph, these being $10^{-0.97}$ for $\alpha$-alanine and $10^{-1.51}$ for $\beta$-alanine.

Table 6 contains a survey of the experimental and calculated values of $k_{\text {amate }}$ and $k_{\text {onate }}$. Considering the nature of the conditions the agreement may be described as satisfactory. 
Table 6. Velocity constants, experimental and calculated.

\begin{tabular}{|c|c|c|c|c|c|c|c|c|c|}
\hline \multicolumn{6}{|c|}{ Initial solution } & \multicolumn{2}{|c|}{$k_{\text {amate }}$} & \multicolumn{2}{|c|}{$k_{\text {onate }}$} \\
\hline & $c_{(\mathrm{AmH})_{2} \mathrm{CO}_{3}}$ & $\begin{array}{c}c_{\text {carba- }} \\
\text { mate }\end{array}$ & $c_{\mathrm{AmH}}+$ & $c_{\mathrm{Am}}$ & $c_{\mathrm{NaOH}}$ & exp. & calc. & exp. & calc. \\
\hline$\alpha$ & $\begin{array}{l}0.02 \\
0.02\end{array}$ & 0.018 & $\begin{array}{l}0.05 \\
0.10\end{array}$ & $\begin{array}{l}0.05 \\
0.10 \\
0.08\end{array}$ & 0.18 & $\begin{array}{l}0.0038 \\
0.0020 \\
0.00043\end{array}$ & $\begin{array}{l}0.0041 \\
0.0021 \\
0.00062\end{array}$ & $\begin{array}{l}0.0013 \\
0.0013\end{array}$ & $\begin{array}{l}0.0013 \\
0.0012\end{array}$ \\
\hline$\beta$ & $\begin{array}{l}0.02 \\
0.02\end{array}$ & $\begin{array}{l}0.019 \\
0.020\end{array}$ & $\begin{array}{l}0.05 \\
0.10\end{array}$ & $\begin{array}{l}0.05 \\
0.10 \\
0.08 \\
0.18\end{array}$ & $\begin{array}{l}0.18 \\
0.18\end{array}$ & $\begin{array}{l}0.0011 \\
0.00048 \\
0.00015 \\
0.00011\end{array}$ & $\begin{array}{l}0.0012 \\
0.00063 \\
0.00025 \\
0.00018\end{array}$ & $\begin{array}{l}0.00085 \\
0.00069\end{array}$ & $\begin{array}{l}0.00087 \\
0.00074\end{array}$ \\
\hline
\end{tabular}

\section{SUMMARY}

The velocity constant of the reaction " $\mathrm{CH}_{3} \cdot \mathrm{CHNH}_{2} \cdot \mathrm{COO}^{-}+\mathrm{CO}_{2}=$ $\mathrm{CH}_{3} \cdot \mathrm{CHNHCOOH} \cdot \mathrm{COO}^{-\prime}$ " and the equilibrium constant for the reaction " $\mathrm{CH}_{3} \cdot \mathrm{CHNHCOO}^{-} \cdot \mathrm{COO}^{-}+\mathrm{H}_{2} \mathrm{O}=\mathrm{HCO}_{3}^{-}+\mathrm{CH}_{3} \cdot \mathrm{CHNH}_{2} \cdot \mathrm{COO}^{-}$" have been determined. The velocity of the decomposition of $\mathrm{CH}_{3} \cdot \mathrm{CHNHCOO}^{-} \cdot \mathrm{COO}^{-}$ in basic medium was investigated and may be explained in assuming that the decomposition is a two-stage reaction, viz.

$$
\begin{aligned}
\text { carbamate } & =\text { alanine }+ \text { carbon dioxide } \\
\text { carbon dioxide } & =\text { carbonate }
\end{aligned}
$$

The carbamate of $\beta$-alanine was studied in a similar way.

\section{REFERENCES}

1. Faurholt, C. Kgl. Danske Videnskab. Selskab, Mat.-fys. Medd. 3 (1921) 20; abstracts in Z. anorg. Chem. 120 (1921) 85 and 122 (1922) 132.

2. Faurholt, C. Kgl. Veterincer-og Landbohøjskoles Aarsskrift 1 (1924); translated into French in $J$. chim. phys. 22 (1925) 1.

3. Lund, V., and Faurholt, C. Dansk Tids. Farm. 22 (1948) 109.

4. Staal, E., and Faurholt, C. Dansk Tids. Farm. 25 (1951) 1.

5. Bjerrum, N. Z. Elektrochem. 24 (1918) 321.

6. Bjerrum, N., and Unmack, A. Kgl. Danske Videnskab. Selskab, Mat.-fys. Medd. 9 (1929) 1.

7. Faurholt, C. Kgl. Veterinoer- og Landbohøjskoles Aarsskrift 1 (1924); translated into French in J. chim. phys. 21 (1924) 400. 